\title{
Stenka Razin's Rebellion: The Eyewitnesses and their Blind Spot ${ }^{*}$
}

ANDRE BERELOWITCH

Richelieu [...] dit avoir reconnu par expérience que, toutes choses égales d'ailleurs, les rebelles sont toujours moitié moins forts que les défenseurs du pouvoir officiel. Même si l'on pense soutenir une bonne cause, le sentiment d'être en rébellion affaiblit. Sans un mécanisme psychologique de ce genre, il ne pourrait y avoir aucune stabilité dans les sociétés humaines.

SimONE WeIL (1909-1943), L'ENRACINEMENT (PARIS, 1949), 261.

J'ai toujours pensé que dans les révolutions, et surtout dans les révolutions démocratiques, les fous, non pas ceux à qui l'on donne ce nom par métaphore, mais les véritables, ont joué un rôle politique très considérable. Ce qu'il y a de certain, du moins, c'est qu'une demi-folie ne messied pas dans ces temps-là et sert même souvent au succès.

Alexis DE TOCQueville, EuVRes, T. XII. SOUVENIRS, ED. LUC MONNIER (PARIS, 1964), 138.

* I wish to thank here the Zentrum für interdisziplinäre Forschung of Bielefeld University for their kind invitation and the Thyssen Stiftung for their generous financial support. I thank for their help Malte Griesse and Marcel Thoene who have kindly accepted to revise the present article. 
Revolts are no ordinary events. They subvert the pattern of society, the established order of things, an order which, in pre-modern Europe, was consecrated by Church and, even more perhaps, by informal belief. ${ }^{1}$ The very real dangers incurred by rebels added to their involuntary feeling of guilt, arousing in them strong, overwhelming emotions, shared also, although in a different key, by their victims. Fueled by these powerful sentiments, hatred, fear, defiance, enthusiasm, and the sheer joy of rebellion, ${ }^{2}$ even a minor revolt soon became known across the borders and stirred trouble, or at least excitement, in far-away countries. Because of the semi-divine nature of Order, still strengthened by the transnational solidarity of monarchs and elites alike, rebellion was resented in neighbouring lands as a scourge to avoid or an example to follow, but in any case as a threat to their usual way of life - all the more so, perhaps, because everyone knew that in given circumstances one might also be tempted to revolt. ${ }^{3}$ That is why representations of revolts, whether domestic or transnational, are very seldom neutral: their authors do take sides, explicitly or not, and nearly always, in the early-modern surviving texts at least, against the insurgents.

1 Even the authority of petty tyrants of the Long Parliament: "To rule is to be sanctify'd", quoth (ironically) Hudibras' squire Ralph (Samuel Butler, Hudibras in three parts, written in the Time of the Late Wars [first published in 1663], part I, canto III, line 1176). Conversely, revolt was condemned by Scripture itself: "For rebellion is as the $\sin$ of witchcraft, and stubbornness is as iniquity and idolatry" (first book of Samuel, 15, 23).

2 "She experienced, for the first time, the terrible beauty of a rebellion [...]; the secrecy, the daring, the anarchic joy of breaking a law, sharpened the excitement of [the] affair", James Ngugi, A grain of wheat, (London [1967], 1974), pp. 44, 59 - a book that was suggested to me by the late Yves Benot. The quotation describes the feelings of a British lady, involved in an extra-marital affair, but is actually meant by the author as a parallel to the Mau-Mau movement in Kenya.

3 In his dissertation, defended in 1674 (see below), Johannes Justus Martius could write: "nec unquam major calamitas fuit, quam cum auctore Stephano Räzino turbæ motusque existerent: nam iis non modo Moscovia metu perculsa, sed etiam tota Europa expectatione futuri eventus aliquandiu suspensa fuit" ["there never was a worse calamity than the riots and rebellion aroused by Stephan Razin, for not only was Muscovy shaking with fear, but the whole of Europe also was for some time in suspense, waiting for the outcome"]. This is confirmed by the reaction of German periodicals: "Zwischen September 1670 und August 1671 ist im Durchschnitt jeder dritten bis vierten Zeitungsnummer eine Meldung über die 'Rebellion in der Moscau' zu entnehmen" (Martin Welke, "Deutsche Zeitungsberichte über den Moskauer Staat im 17. Jahrhundert", Russen und Russland aus deutscher Sicht 9.-17. Jahrhundert, M. Keller, ed., (München, 1985), p. 264-286, 279. 
The contemporary sources about the Razin rebellion, which has been chosen as a case for study in the present paper, are no exception to the rule. If we put aside a few "enticing letters" [prelestnye pis'ma], which were part of the rebels' propaganda, all foreign relations of the revolt, all Russian documents pertaining to it condemn Razin and his followers. Not so the Russian folklore: Razin's legend conveys a belated echo of favourable popular feeling. ${ }^{4}$

Representations may be, and often are, analyzed for their own sake: in order to recapture the point of view of the observer, the historian's attention is focused not on the actual events, but on the arrangements and distortions they are subjected to in the narrative. Radical sceptics even argue that representations are the only source available to us, since any conceivable document, be it manor accounts or a ship's bill of lading, endeavours to present facts in a certain light - in other words, the simple act of writing something down is already, to some extent, tampering with reality.

These objections notwithstanding, and believing that cross-checking sources against one another provides a sufficient degree of probability, I will try to relate representations to known facts so as to throw some light on both phenomena. The very nature of the task restricts the circle of acceptable evidence: second-hand or third-hand accounts are more informative about public opinion, i.e. about the historian's or the compiler's mind, than about the actual features of the rebellion. Only narratives written by eyewitnesses, only documents issued by agents on both sides can answer two questions I would like to put to the test: can we ascribe a social nature to Razin's uprising? What kind of mechanism triggered the revolt at the crucial moment? Before dealing with these topics, I will give, by way of introduction, a survey of the available sources, a summary of the events, ${ }^{5}$ and devote some space to a seemingly irrelevant problem: how much did $17^{\text {th }}$ century Muscovites, on both sides, care about representation?

\section{Available SOURCES}

The bulk of the domestic sources on the Razin rebellion (razinshchina) has been published by Soviet historians between 1954 and 1976, under the highly ideological

4 Philip Longworth, "The subversive legend of Sten'ka Razin”, Russia/Rossiia. Studi e ricerche a cura di Vittorio Strada, $\mathrm{n}^{\circ}$ 2, 1975, 17-40.

5 A more detailed account in English: Paul Avrich, Russian Rebels 1600-1800 (New York, London, 1972), chapter II. 
title Peasant War under the Leadership of Stepan Razin. Documents. ${ }^{6}$ Quite a few additional materials have appeared since 1976. However, these documents will be mainly used to check foreign sources, the only ones that are, strictly speaking, in keeping with our subject.

Not surprisingly, since Russia was at the outskirts of Europe, foreign sources are few, if we put aside second-hand narratives and various compilations, and make use only of reports by eyewitnesses. ${ }^{7}$ Four Dutchmen have described the early course of the rebellion. The author of the Letter written on board [...] the Orel, [...] September $24^{\text {th }} 1669^{8}$ is unknown, but very probably was a member of the Dutch crew of this first warship, Western fashion, ever built in Muscovy. David Butler, skipper, and Jan Janszoon Struys (ca 1630-1694), sailsmaster on the Orel, were ordered to join Astrakhan garrison, when the town was put under siege by Razin's army. ${ }^{9}$ All of them took some part in the defense of the city and managed

6 Krest'ianskaia voina pod predvoditel'stvom Stepana Razina. Sbornik dokumentov, vol. I, II/1-2, III, IV (Moscow, 1954-1976) [hereafter: Krest'ianskaia voina]. Nearly all are official documents, the only exceptions being the "enticing letters" mentioned above.

7 Since M. N. Tikhomirov's not very satisfactory and outdated essay "Istochniki po istorii razinshchiny”, Problemy istochnikovedeniia, I (Moscow-Leningrad, 1933), p. 50-69, no recent study, as far as I know, has dealt with the foreign narratives of Stenka Razin's rebellion as a whole. They have been conveniently put together and published in Leningrad by A. G. Man'kov, in: Zapiski inostrantsev o vosstanii Stepana Razina (Leningrad, 1968) [hereafter: Zapiski], and Inostrannye izvestiia o vosstanii Stepana Razina, 1975 [hereafter: Inostrannye izvestiia]. Texts are printed both in the original languages and in Russian translation. The latter book includes extracts from chiefly German, but also French periodicals. Man'kov describes foreign Razin narratives in general (Zapiski, 5-13, 84-87), and so does Serge Konovalov in his "Ludvig Fabritius's Account of the Razin Rebellion" $O x$ ford Slavonic Papers, VI, 1956, p. 72-94, $72-73$ [hereafter: Fabritius], and in "Razin's Execution. Two Contemporary Documents", S. Konovalov, ed., Oxford Slavonic Papers, XII, 1965, p. 94-98, 94 [hereafter: Razin's Execution].

8 Unless otherwise specified, all dates are given in the Julian calendar. In quotations of English or French texts of the $17^{\text {th }}$ century, spelling has been conserved, punctuation slightly modernized.

9 The anonymous letter, Jan Struys' narrative and a letter written by David Butler from Ispahan, March $6^{\text {th }}, 1671$, are to be found in: Jan Struys, Drie aanmerkelijke en seer rampspoedige reysen door Italien, Griekenlandt, Lijflandt, Moscovien, Tartarijen, Meden, Persien, Oost-Indien, Japan [...] (Amsterdam, 1676). Being unable to use the Dutch original, I have quoted here from the English The Perillous and most unhappy voyages of John Struys through Italy, Greece, Lifeland, Moscovia, Tartary, Media, Persia, East-India, Japan and other places in Europe, Africa and Asia [...] to which are 
eventually to escape from Razin's camp. So did Ludvig Fabritius (1648-1729), a young foreign officer who had already served nine or ten years in the Russian army, and came with the strong detachment sent up the Volga from Astrakhan against the rebels. ${ }^{10}$ His account is the best by far, at the same time simple, clever and unbiased, although written some twenty years after the event. The others rather tend to mingle facts with moral and political considerations.

Another group of foreigners, who were not involved in the events, but lived in Moscow at that time and wrote about Russia, seem to have witnessed the arrival of Stepan Razin in Moscow and his execution. Their accounts are especially valuable since only one report by a Russian eyewitness has been found. ${ }^{11}$ The anonymous author, perhaps a Dutchman, of A Relation concerning the particulars of the Rebellion lately raised in Muscovy by Stenko Razin, who gave the most accurate account of the whole course of the rebellion, had probably access to official documents as well. ${ }^{12}$ Thomas Hebdon, an English merchant, brother of the wellknown diplomat John Hebdon the Elder, is the most reliable witness: on the very day of Razin's death, he wrote a letter describing his execution. ${ }^{13}$ Johannes Justus Merz, latine Martius, (1648-1702), a Lutheran minister who worked from 1668 to 1672 as a school teacher in the Foreign Quarter in Moscow, wrote a dissertation on

added 2 narrativs sent from Capt. D. Butler relating to the taking in of Astrachan by the cosacs [...] rendered out of Nether-dutch by John Morrison (London, 1686) and the French translation Les Voyages de Jean Struys, en Moscovie, en Tartarie, en Perse, aux Indes \& en plusieurs autres païs étrangers (Amsterdam, 1681) [both hereafter: Struys].

10 Fabritius' memoirs have remained manuscript until Konovalov's publication. The original German text is in Zapiski, 14-46; quotations in this paper are from Konovalov's English translation, see footnote 9 above.

11 Krest'ianskaia voina, IV, $\mathrm{n}^{\circ}$ 66-67, p. 61-62.

12 For conjectures about the author, see: A. L. Gol'dberg, "Soobshchenie o vosstanii Stepana Razina", Zapiski, p. 157-165. The Relation was first published in Dutch: Kort Waerdachtigh verhael van de bloedige Rebellye in Moscovien [...] (Haerlem, 1671) and in German: Kurtze doch Warhafftige Erzählung von der blutigen Rebellion in der Moscau [...] (Emden, 1671). The English text was printed in Newcomb, 1672, and is reproduced, with Russian translation, in Zapiski, p. 84-126 [Hereafter quoted: Relation]. The French version Relation des particularitez de la rebellion de Stenko Razin contre le grand-duc de Moscovie (Paris, 1672); repr. by Augustin Golitsyn (Paris, 1856) was translated from the English.

13 His letter, written in Moscow on the $6^{\text {th }}$ of June 1671, to Richard Daniell, an English resident in Riga, in Razin's Execution, p. 97-98. 
Stepan Razin, defended in July 1674, and published in the same year. ${ }^{14}$ His information is partly derived from his readings, but his impressions on the mood of the Moscow crowd are undoubtedly his own. ${ }^{15}$ Jacob Reutenfels was a spectator of Razin's "horrible" death. ${ }^{16}$ All other accounts may safely be ignored for the purposes of the present paper. $^{17}$

14 Merz's biography by A. K. Gavrilov in Inostrannye izvestiia, p. 25-30. His dissertation: Martius, Johann Justus, стенко разинъ донски козакъ изменникъ, id est Stephanus Razin donicus Cosacus perduellis, publica disquisitioni exhibitus, praeside Conrado Samuele Schurzfleisch, respondente Johanne Justo Martio, Mulhusa-Thuringo, d. XXIX Quintil. Anno M DC LXXIV, Wittenbergæ Ex officina Christiani Schröteri. It was reprinted in Leipzig (1679), in Wittenberg (1683) and again in Leipzig (1698). Repr. in Inostrannye izvestiia, p. 31-75 (Latin original and Russian translation). Partial English translation (§ 27-30), Razin's Execution, p. 95-96.

15 "Ita ex commentariis actorum Russicorum didici" ( $\$ 25^{*}$, Inostrannye izvestia, p. 48: "So I learnt from russian writings"); "Ipse pro comperto habeo, quam parum omnes ab exitio abfuerint" ( $§ 22$, ibidem, p. 47 : "I hold for certain that we all narrowly escaped being killed").

16 "Horrendum ejus modi inusitatioris supplicii specimen in Stenka, seu Stephano Rasin Cosaco rebelli Moscuæ spectavimus" ["A horrifying instance of this unusual kind of death we have seen in Moscow when Stenka, i. e. Stepan Razin, a rebel Cossack, was executed"], in: Yacobus Reutenfels, De rebus Moschoviticis ad Serenissimum Magnum Hetrurice Ducem Cosmum Tertium (Patavii, 1680); facsimile edition by Marshall Poe: Early Explorations of Russia, vol. XI (London, New York, 2003), p. 164; German translation: Yacob Reutenfels, Das grosse und mächtige Reich Moscovice [...] (Nürnberg, 1687). Reutenfels (actually spelled "Rautenfels") lived in Moscow from 1670 to the spring of 1672, cf. Claudia Jensen, Ingrid Maier, "Orpheus and Pickleherring in the Kremlin”, Scando-Slavica 59:2, 2013, 145-184, 148-150

17 "A Narrative of the Greatest Victory known in the Memory of Man: Being the total Overthrow of the Great Rebel Stepan Radzin [...]", Inostrannye izvestia, p. 8-10; "Ritratto della Moscovia. Ristretto geografico, historico e genealogico del gran Ducato o sia Impero di Moscovia”, A. I. Turgenev, ed, Historica Russiæ Monumenta, II, Petropoli, 1848, p. 249-278; Historisch Verhael, of Beschrijving van de Voyagie, gedaen onder de Suite van der Heere K. van Klenk (Amsterdam, 1677), repr. with Russian translation, A. M. Lovjagin, ed., Posol'stvo Kunraada fan-Klenka [...], (Saint Petersburg, 1900); Carl Valerius Wickhart, Moscowitische Reise-Beschreibung [...] (Vienna, 1675), p. 201-202. 


\section{SUMMARY OF THE EVENTS}

It is no coincidence if Razin's first expedition (1667) starts at the end of the Thirteen Years, Russian-Polish War (1654-1667), at a moment when Russian taxpayers are at the end of their tether (taxes in grain alone have increased fourteenfold between 1620 and 1670), the Treasury runs short of money, and military men are no longer needed. All these factors help to understand the difficult position of the semi-independent Don Cossacks, who fought alongside of Muscovite troops when they saw fit, and in return received subsidies from Moscow (grain, powder, cash and arms), yet derived part of their income from plundering raids, chiefly, but not exclusively, directed against Crimean and Ottoman territories. ${ }^{18}$ No wonder if the Russian government wanted to curb as much as possible the political freedom of the Cossacks. A particularly sensitive topic was the problem of fugitive peasants, who often joined the Cossack Host. Moscow insisted on having them returned, but the Don Cossacks, many of whom were themselves ex-fugitives, took pride in refusing. Razin would say in 1669: "It is not the custom among Cossacks to hand over runaways." 19

One way of achieving control over the Cossacks was to reduce, postpone or even cut out the Don subsidies, another - the military colonisation of the South, on the Belgorod Abatis line. Both led to unexpected results: since supplies were lacking, the Cossacks switched to plundering, the only way left to survive. Colonisation, undertaken, of course, to defend Russian territory against Crimean raids, but also to keep an eye on the Host, brought thousands of deserters and fugitive peasants into the Don region, thus creating a situation close to famine. ${ }^{20}$ Since economic and social differentiation was already well advanced among the Host, those who suffered most were the poorer Cossacks (golutvennye ljudi), as opposed to their well-to-do (domovitye) brethren. ${ }^{21}$

18 Brian Davies, "Muscovy at war and peace", The Cambridge history of Russia, I: From Early Rus' to 1689, Maureen Perrie, ed. (Cambridge, 2006), p. 486-519, 493. Whenever possible, I have translated Russian terms in accordance with this edition.

19 Maureen Perrie, "Popular Revolts", ibidem, p. 600-617, 605; Viktor Ivanovich Buganov, Krest'ianskie voiny v Rossii XVII-XVIII vv., Moscow, 1976, p. 60, 71, 82 [hereafter: Buganov].

20 Davies, p. 499; Krest'ianskaia voina, I, $\mathrm{n}^{\circ}$ 38, p. 73: according to a report from the governor of Tsaritsyn, 14 March 1667, "fugitive bondsmen [holopy] and peasants from the border, with wives and children, have taken refuge in many villages of the Don region, and because of that there is now a terrible famine on the Don."

21 A view contested by Nikolai Ivanovich Nikitin, "O formatsionnoi prirode rannikh kazach'ikh obshchestv (K postanovke voprosa)”, Feodalizm v Rossii [Festschrift for L. V. 
A minor, but ominous, episode occurred in June of 1666. A 700 men strong Cossack detachment under Vasilii Us (Basil "Moustache") rode North, allegedly to offer their services as cavalrymen to the tsar. A deputation was indeed sent to Moscow, but met with a flat refusal and was ordered to go back to the Don. Meanwhile, Us and his men had moved their encampment further North to Tula, attracting quite a number of local peasants and bondsmen (see below) and looting noble estates in the vicinity. They withdrew in July only under military coercion. Not surprisingly, Us in time became one of Razin's lieutenants. ${ }^{22}$

The Andrusovo armistice (January 1667) didn't improve the situation in the least. Tsar Alexis said as much in his letter to the shah of $\operatorname{Iran}^{23}$ : "It has come to our knowledge that after we had made peace with the kingdom of Poland, bandits and fugitives from various places have appeared on the lower Volga" (May $3^{\text {rd }}, 1668$ ). A little later, in his message to the governor of Tsaritsyn, Razin provides the explanation: "In the Host, there is nothing left to eat or to drink, whereas the tsar's subsidies in money and grain are sent sparingly. That's why we went to the Volga, to feed ourselves." 24

During the spring of 1667 , small bands of Cossacks made their way to the Volga, where they attacked Russian convoys, and to the Caspian Sea, where their targets were Persian ships. They endangered thereby Russia's good relations, and particularly trade, with Iran. Local governors soon put an end to these first attempts at piracy, but they were less successful against the large-scale expedition led by Stepan Timofeevich Razin. ${ }^{25}$

Razin, born ca. 1630, belonged to the Cossack elite. Up to 1667 his life was in no way remarkable, at least according to the little information available. ${ }^{26}$ He took part, in 1658, in a Cossack deputation to Moscow. Three years later, as a Don Cossacks' representative, he was a member of the embassy led by secretary Ivan Savvich Gorohov to meet Kalmyk tayishis Daichin and Monchak/Puntsuk. ${ }^{27} \mathrm{He}$

Cherepnin], Moscow, 1987, p. 236-245, who argues that Cossack society was "prefeudal" and still primitive, nay regressive, in many ways. His analysis of Cossack way of life (p. 236-239) is remarkably lucid.

22 M. Perrie, loc. cit.; more details in Buganov, p. 62-66.

23 Buganov, p.71.

24 Ibidem, p. 72.

25 The diminutive of Stepan, "Stenka", used in Muscovite official documents, is a pejorative, indicating either young age or a low status in the social hierarchy.

26 Buganov, p.66-70; Ocherki istorii SSSR. Period feodalizma XVII v. (Moscow, 1955), p. 283 [hereafter: Ocherki].

27 About this embassy, see Michael Khodarkovsky, When Two Worlds met. The Russian State and the Kalmyk Nomads, 1600-1771, Cornell UP, Ithaca and London, 1992, p. 95. 
then headed a Cossack detachment sent against Crimean Tatars in 1663. Meanwhile, he twice asked permission to make a pilgrimage to the Northern convent of Solovki (1652, 1661).

In 1667, however, he takes the lead of the Cossack bands which are gathering again near the portage between Don and Volga rivers. As soon as the ice breaks on the Don (mid-April 1667), Razin and his 600 followers sail towards Panshin and Kachalinsk, where the river islands are well out of reach for regular forces. There he carefully prepares his campaign, recruiting men among Cossacks and "fugitives from various places", stocking up plundered arms, ammunition, food and equipment. Part of the weaponry is provided by well-to-do Cossacks to individual members of the expedition, on a fifty-fifty (ispoly) basis, meaning that the investors would receive half of the expected booty. "It would be wrong", writes Viktor Buganov, "to deny the predatory aspects" of Razin's voyage. ${ }^{28}$ We may add that, mutatis mutandis, the management of this expedition is in many respects similar to the raids of the freebooters and buccaneers in the West Indies, as described by Exquemelin. $^{29}$

Once ready, Razin enters the Volga with his bands, now 1500 men strong: the flotilla heads South, past Tsaritsyn. Razin dodges or overcomes the detachments sent against him from Astrakhan. He already applies the tactics to which he will stick until the end of the movement: nobles, officers, merchants are put to death, as well as the rank and file who resist him; the rest switch sides and join the Cossacks. At last, between June $3^{\text {rd }}$ and $5^{\text {th }}$, the Cossacks sail past Astrakhan by night, and enter the Caspian Sea. In July, disguised as pilgrims, they take the fort of Iaitsk by trickery, and there they remain during the winter of 1667-1668. All attempts made by the Russian government first to negotiate with Razin, then to drive him out of his stronghold, have failed. ${ }^{30}$

Very little reliable information about Razin's sea voyage is available to historians, since no research has been as yet conducted in Persian archives. ${ }^{31}$ As far as we know, the Cossacks abandoned Iaitsk in March 1668, and sailed southwards,

28 Buganov, p.72, 73.

29 Original Dutch edition: Alexander Exquemelin, De Americaensche Zee-Roovers, Amsterdam, 1678, followed by German (Nürnberg, 1679), English (Bucaniers of America, London, 1684) and French (Paris, 1686) translations.

30 Ocherki, p. 286.

31 All accounts are only by hearsay, be it the reports of Russian town governors (in Krest'janskaja vojna), or the narratives of European travellers: Jean Chardin (1643-1713), who was in Persia at the time (Le Journal de voyage du chevalier Chardin en Perse et aux Indes orientales, Amsterdam, 1711), and Engelbert Kaempfer (1651-1716), who arrived in Isfahan in 1683 (his account in Inostrannye izvestiia, p. 152-180). 
following the Western coast of the Caspian Sea, plundering ships and even towns (Derbent, Baku) as they went along. They freed Russian captives, and made prisoners among Persian population, to be bartered later or sold into slavery. ${ }^{32}$ Alternating success and defeats, they accumulated considerable wealth, periodically divided between the fighters, ${ }^{33}$ but often suffered from illness and starvation. In the spring of 1669 , Razin decided to offer his services to the shah. ${ }^{34}$ But the Persian ruler had Razin's envoys executed, and sent troops against the Cossacks. Taken by surprise near Rasht, they took revenge on the city of Farahābād and, after defeating a Persian flotilla, sailed back towards Astrakhan in July 1669.

Since he had been forbidden to sail into the Caspian Sea, Razin, entrenched in the Four Hills island at the mouth of the Volga, feared new attacks from Astrakhan. He certainly didn't expect the third in command in the city, prince Semen L'vov, escorted by three or four thousand men with artillery, to present him a letter issued by the tsar in 1667, forgiving the Cossacks their faults if they promised to behave in the future.

So it came that Razin and his men, "everyone of them appearing in the most splendid manner he could", scattering gold coins to admiring crowds, ${ }^{35}$ made a triumphant entry into the town. Far from acting as repentant sinners, the pirates, while negotiations went on, sold slaves, beautiful cloth and jewellery in the market place, thus making a deep and lasting impression on the local population. ${ }^{36}$ The governors were even given generous presents by Razin himself. Finally, the Cossacks were allowed to sail back to their homes on the river Don, where they arrived in October 1669.

32 Slavery is present everywhere in this story: Razin wants to free Russian peasants from it, but his Cossacks sell their Persian captives, and the defeated rebels are, in their turn, illegally enslaved by their victors (cf. Krest'ianskaia voina, III, $n^{\circ} 11$, p. $12 ; n^{\circ} 15$, p. 15), e. g. by Ivan Bogdanovich Miloslavskii (ibidem, $\mathrm{n}^{\circ} 205$, p. 230) and many others (ibidem, $\left.\mathrm{n}^{\circ} 31,45,213\right)$.

33 This was called duvanit', from duvan (a derivative of turcic divan), meaning the place where the warriors assemble, or the booty itself, human or otherwise.

34 Kaempfer, Inostrannye izvestiia, p. 158.

35 "For they had rifled many Gentlemens Houses where they found always Apparrel, Jewels and other Plunder for Habit and Ornament", Struys, p. 186 ; "La plupart du peuple \& des soldats, qui couroient en foule auprès de lui lorsqu'il paroissoit dans les ruës, \& auxquels il jetoit souvent des poignées de ducats", Struys, p. 176.

36 Fabritius, p. 79 : "This human market lasted some six weeks" [...] He [Razin] promised to free them [Astrakhan common people] from the yoke of the boyars ant set the slaves free, so that the people listened to him gladly and promised to help him with all their might as soon as he was ready to begin his attack." 
The whole Persian campaign looks very much like a rehearsal of the next, so purposeful were Razin's moves between the autumn of 1669 and the spring of 1670. Contrary to custom, he did not disband his troops, but kept them in a fortified island under strict discipline, while using what was left of the booty to arm and equip his small army, which was steadily growing in numbers: "He began straightaway quietly gathering the common people around him, giving them money, and promises of great riches if they would be loyal to him and help to exterminate the treacherous boyars. ${ }^{, 37}$ By May 1670, Razin had under him four or five thousand men.

Already in March, the Cossacks, assembled in a "ring" (krug), ${ }^{38}$ had been consulted about the choice of a target for the next expedition. They rejected Azov, as well as the Russian project ("go to Russia and fight the boyars"), and adopted enthusiastically the Volga instead. After killing two nobles sent by the tsar to report on Razin's movements (April), the army arrived, probably on May $13^{\text {th }}$, in Panshin. Another circle was summoned, which confirmed the previous decision, but with a significant addition. When asked: "Would you all go from the Don to the Volga, and from the Volga into Russia against the sovereign's enemies and traitors, to rid Muscovy of treacherous boyars and Duma [conciliar] people, and, in the provinces, of governors and administrators?", the Cossacks answered in the affirmative. ${ }^{39}$

Meanwhile, the authorities, who were kept informed by governors and spies, had sent a thousand musketeers [strel'tsy] under Ivan Lopatin down the Volga. ${ }^{40}$ Another, much more important force (several thousand men commanded by prince Semen L'vov), was slowly moving up river from Astrakhan. When Razin arrived under Tsaritsyn, both armies were still on their way. The town was given over to the Cossacks by its revolted dwellers, and Razin immediately marched against Lopatin, whom he met and defeated some five miles upstream. The greater part of the musketeers were slaughtered, the rest joined the Cossacks or were pressed into service as oarsmen. Razin then turned around to meet the L'vov army, which he

37 Fabritius, p. 79-80.

38 "A Krug is a meeting convened by order of the Ataman [elected chief, A.B.], at which the Cossacks stand in a circle with the standard in the centre; the Ataman then takes his place beside his best officers, to whom he divulges his wishes, ordering them to make these known to the common brothers and to hear their opinion of the matter : if the proposals of the Ataman please the commoners, they all shout together 'Lyubo, lyubo'“ (ibidem, p. 81)

39 Buganov, p. 83-88.

40 A picture designed to entertain and instruct tsar Alexis' children represents the flotilla on its way to Tsaritsyn. Cf. Z. I. Fomicheva, "Redkoe proizvedenie russkogo iskusstva XVII veka”, Drevnerusskoe iskusstvo. XVII vek (Moscow, 1964), p. 316-326. 
found under Chernyi Yar. This is how Fabritius describes the battle (June $11^{\text {th }}$, 1670):

The next morning, at 8 o'clock, our look-outs on the water came hurriedly and raised the alarm as the Cossacks were following at their heels. [...] In the meantime Stenka prepared for battle and deployed on a wide front; to all those who had no rifle he gave a long pole, burnt a little at one end, and with a rag or small hook attached. [...] The common soldiers imagined that, since there were so many flags and standards, there must be a host of people. They put their heads together and at once decided that this was the chance for which they had been waiting so long, and with all their flags and drums they ran over to the enemy. They began kissing and embracing one another and swore with life and limb to stand together and to exterminate the treacherous boyars, to throw off the yoke of slavery, and to become free men.

The general with his officers sought refuge in the Chernyi Yar fortress, but the garrison had also mutinied, and all eighty men were taken prisoners.

Murder at once began. Then, however, Stenka Razin ordered that no more officers were to be killed, saying that there must be a few good men among them. [...] A Krug was accordingly called and Stenka asked through his lieutenants how the general and his officers had treated the soldiers under their command. Thereupon the unscrupulous curs, streltsy as well as soldiers, unanimously called out that there were not one of them who deserved to remain alive, and they all asked their father Stepan Timofeyevich Razin should order them to be cut down. This was granted with the exception of General Knyaz Semen Ivanovich L'vov ${ }^{41}[\ldots]$ The officers were now brought in order of rank out of the tower [...], their ropes were cut and they were led outside the gate. When all the bloodthirsty curs had lined up, each was eager to deal his former superior the first blow, one with the sword, another with the lance, another with the scimitar, and other again with martels [...] Indeed, some were cut to pieces and straightaway thrown into the Volga. ${ }^{42}$

The road to Astrakhan was now open. The city was defended by 6.000 soldiers and 500 guns; Razin, however, had not only won over the town people ${ }^{43}$, but also the

41 In return for Razin's presents, in 1669, L'vov had given him "a beautiful gold-plated image of the Virgin" (Fabritius, p. 79), and the Cossack chief became the prince's sworn brother. That is probably why Razin spared L'vov until his own death on the scaffold (ibidem, p. 83, footnote 1).

42 Fabritius, p. 81-82.

43 "The report of these things [news from Chernyi Yar] [...] gave the Rabble greater Occasion to mutiny than they had before, yea, so far $[\ldots]$ that they publicly reproached the $\mathrm{Su}$ periority that they durst not look out of their doors or windows, much less walk the streets 
garrison itself. In the night of $21^{\text {st }}$ to $22^{\text {nd }}$ June, the city was easily taken, and the sequence of events in Tsaritsyn or Chernyi Yar, repeated: governors, officers killed along with the loyal soldiers; their goods plundered and divided among the rebels; new recruits rushing into Razin's army and henceforth decreed Cossacks. ${ }^{44}$ Astrakhan civilians were, likewise, democratically organized: they discussed their affairs in krugs, and elected their own atamans (Vasilii Us a popular winner). All official archives were systematically lacerated, especially indentures, thereby putting into effect Razin's promises about "setting the common people free."

On the $20^{\text {th }}$ of July 1670 , Razin departed from Astrakhan with 11000 men, leaving 2000 behind. Stopping briefly in Tsaritsyn (4-7 August), he sent two detachments to stir up revolt in Ukraine, and moved up to Saratov, then to Samara, which didn't even resist the rebel army. These were his last victories. He tried in vain to secure Simbirsk, a strategically important point on the Abatis line, defended by Ivan Miloslavskii. Razin took the town, but was unable to capture the citadel (September $5^{\text {th }}-6^{\text {th }}$ ), which he put under siege for a whole month. This delay proved fatal to the movement. In the beginning of October, Simbirsk was rescued by Iurii Boriatinskii. Razin, wounded, was carried away by devoted followers and disappeared from the scene until his final capture.

This did not stop the rebellion; although the main rebel army had been defeated, Razin's lieutenants did not give up the struggle. Moreover, independent detachments, sometimes several thousand men strong, gathered in different parts of the countryside, mainly in the Middle Volga region. They took a few secondary towns, such as Penza, Temnikov, Alatyr', and even marched on Arzamas, then headquarters of the repression. Here, under Iurii Dolgorukii, were concentrated, summarily judged and executed up to 11000 insurgents: "The place was terrible to behold, and had the resemblance of the Suburbs of Hell." 45 Razin himself, captured on April $14^{\text {th }}, 1671$ by the notables among Don Cossacks, was brought to Moscow and executed on June $6^{\text {th }}$ of the same year. The rebel city of Astrakhan surrendered to Ivan Miloslavskii only on the $27^{\text {th }}$ of November. This was the last of the

$[\ldots]$, for it was no rare thing now to see the Rabble assemble together in heaps, and before the Doors of the Magistrates, to cry out with infamous and bitter Railings, Now, now, the times begin to alter, it will be our turn next to Lord it, you villains" (Struys, p. 208).

44 After his escape, Fabritius is dressed Cossack fashion : "my [former] orderly [...] cut my long hair - detested by the villains $-[\ldots]$ and gave me a rough coat made of coarse sacking." (Fabritius, p. 82).

45 Relation, p. 98. 
razinshchina, which, according to the Relation, had mobilized up to 200000 men, ${ }^{46}$ but not the last of Russian revolts. Just as some of Razin's companions had already taken part in the "Copper sedition" (1662), so did Viktor Buganov find survivors of the 1670-1671 civil war among the revolting musketeers in Moscow (1682), or even the Bulavin's Cossacks (1707-1708). ${ }^{47}$

\section{REAPPRAISING THE EVIDENCE}

Such is, by and large, the picture resulting from the foreign narratives of Razin's rebellion, if we exclude the abuse showered on its agents. It does not substantially differ from the standard version of the events approved by Soviet historians, except for rhetorical effects about the ruthless ruling classes and the splendid courage of the exploited. Actually, the obsessive class-struggle motif blocked innovative interpretation of the razinshchina for the better part of the last century, roughly from the provocative article by Andrei Kabanov, ${ }^{48}$ published in 1917 , to the paper by Michael Khodarkovsky in $1994 .^{49}$ Although the latter mainly discusses the more general problem of "peasant wars", both analyze in some detail the behaviour of the rebels and of the authorities. I will try to follow in their steps, adding some comments of my own.

Khodarkovsky has shown that, from the point of view of the Moscow government, incursions such as Vasilii Us's foray near Tula, or even the Caspian expedition of Razin were not considered as extraordinary, and certainly not as a revolt: "Like their nomadic neighbours, the Cossacks traditionally displayed their

46 "It was of great importance to Russia, and a great Mercy of God, that the Rebels lay here and there divided; as also, that they could not agree among themselves, about the Supream Command. For if this power of the Rebels, consisting of Two hundred thousand Men, had been united and unanimous, it would have been difficult for the Forces of the Czar to have resisted and mastered the same" (ibidem, p. 99).

47 Buganov, p. 106, 112.

48 A. K. Kabanov, "Razintsy v Nizhegorodskom krae (priemy bunta i usmireniia)" ["Razin's followers in the Nizhnii-Novgorod region (ways and means of revolt and repression)"], Sbornik statei v chest' Matveia Kuz'micha Liubavskogo, Petrograd, 1917, p. 413-428. On the tragic fate of Andrei Kiprianovich Kabanov (1876-1922), who was arrested by the Cheka and died while serving a sentence of one year forced labour for counterrevolutionaty activities, cf. A. A. Kuznetsov, A. V. Mel'nikov, B. M. Pudalov, "Novye dannye o sud'be nizhegorodskogo istorika Kabanova", on the site: www.opentextnn.ru.

49 M. Khodarkovsky, "The Stepan Razin Uprising: was it a 'Peasant War' ?”, Jahrbücher für Geschichte Osteuropas, Neue Folge, vol. 42/1 (1994), p. 1-19. 
ultimate dissatisfaction by turning against Moscow. When requests and complaints failed, military action was usually more effective in attracting the government's attention." 50

When the Nogays brought horses to sell to Moscow (a vital supply for Russian cavalry), ${ }^{51}$ the authorities knew that plundering on the way, sometimes on a major scale, was unavoidable. That was the price to pay if one wanted to have nomads at one's service. The fact that most of the Cossacks were orthodox and, in a very broad sense, considered themselves Russians made no difference in that respect. Like the garrisons on the Ottoman-Habsburg borders, they may be described as "march warriors", "living according to their own rules and codes of conduct.",52 Forced tolerance of nomadic excesses explains why in 1667 Razin, when "only" guilty of piracy on the Volga (he was still on his way to the Caspian Sea), was granted a letter of grace by the tsar, forgiving his past misdeeds, provided he promised to sin no more, ${ }^{53}$ and also why, when returning from Persian shores, he was pardoned on the strength of that very same letter, and allowed to go home with his unruly band.

By May of 1670, of course, rebellion became obvious and was named as such in official documents. Even then, forgiveness remained an option if the culprits duly expressed repentance. In the initial stage at least, negotiation was not excluded, and no visible barrier, as yet, separated the rebels from the loyal subjects of the tsar. ${ }^{54}$ Both sides, as Kabanov has shown, tried to win over people who were hesitating on the brink of rebellion, and used strikingly similar methods to do so. Both drafted letters and manifestos, written by the tsar, his officials, the patriarch or the commanding officers in the field, or conversely by Razin himself or his lieutenants. Both found means to circulate these letters among the population, and both, when they could, wielded more potent arguments such as axes, swords, muskets or the gallows.

50 Ibidem, p. 9.

51 Khodarkovsky, When Two Worlds met, p. 28.

52 Peter F. Sugar, "The Ottoman 'professional prisoner' on the Western Borders of the Empire in the sixteenth and seventeenth centuries", Études balkaniques, 1971/2, p. 82-91, 82.

53 Buganov, p. 75-76.

54 In October 1670, two Chuvash hundredmen, loyal to the tsar, met a Chuvash imam (abyz) who was on the side of the rebels. After both parties had sworn not to shoot at each other, the imam departed, leaving "enticing letters" enclosed in a bark-box (Krest'ianskaia voina, II/1, n 90 , p. 105-106). 


\section{Circulating the Written Word: The Rebels}

As a rule, Razin's followers couldn't spell, so finding able writers was something of a problem. They managed, nevertheless, with the help of local literati, parish clergymen, sextons, local clerks, and the like, ${ }^{55}$ and disseminated the messages as best they could. For instance, in October 1670, the small town of Saransk is stormed by a troop of Simbirsk musketeers and Cossacks, led by a Don Cossack. All the prisoners of the city jail are released, one of them is appointed ataman, who then does the round of the villages, handing out "enticing letters" copied by a clerk in Temnikov. ${ }^{56}$ A letter, addressed to the "populace" of the Tsivil'sk district and delivered by Cossack Kildibiakov, bids the peasants to turn the text over to local village sextons to have it copied word for word, and then to distribute the copies in villages and hamlets "so that everybody in the district would be acquainted with it., 57

For the same reason, viz. general illiteracy, the messages were read in public, as e. g. at Unzha (a small town in the Galich district): "the local elder, Tarasko Grigor'ev, in lieu of the town crier, made the announcement on the market place, and the blackguardly letter was read by the town priest of Saint-Makarios, Timofei Andronnikov." ${ }^{58}$ Reading messages from loyalists was quite naturally forbidden: in April 1671, a sexton pressed into service by the Cossacks (or so he said) stated that "as I read to the assembled people the letters sent by the nobles from the other side of the river, the rebellious Cossacks forbade the people to listen." 59

Communication, however, was not achieved purely by means of words. Rebel chiefs were not adverse to some show of ceremony: "the criminal Il'iushka Ivanov [a well-known Razin's lieutenant, A.B.] [...] sent ahead scouts, to make sure that the priest would meet him with icons, and peasants with loaves of bread. And if anyone refused to do so, he would have everybody cut down and our houses

55 E.g. in the Shatsk region: "Among the bandits [rebels, $\mathrm{AB}$ ] it was the sexton, Liubim Selivanov, whose surname I don't know, who wrote the letters" (ibidem, II/1, n 224, p. 273; November 1670). Sergei Ignat'ev, public writer on oath [ploshchadnoi pod'iachii] in Tambov, "wrote, he says, for the lawless Cossacks all kinds of letters" (ibidem, II/1, $\mathrm{n}^{\circ}$ 285, p. 359; December 1670).

56 Ibidem, II/1, n 110, p. 128-130; October 1670.

57 Ibidem, II/1, n 78, p. 91; September 1670.

58 Ibidem, II $/ 1, \mathrm{n}^{\circ} 288$, p. 362; December 1670 . Similarly, a letter from Razin to his followers in Tsaritsyn is read aloud in the krug (ibidem, $I, n^{\circ} 150$, p. 210; July 1670).

59 Ibidem, III, $\mathrm{n}^{\circ} 47$, p. 55. 
destroyed." ${ }^{60}$ Since this is an answer to official inquiry, the peasants pretend that they were forced to join the rebellion, which may or may not be true. But some of the few extant "enticing letters" are quite explicit:

We beseech you to show your zeal for the house of the holy Mother of God, and for the great sovereign [tsar Alexis], and for your father [batiushka] Stepan Timofeevich [Razin], and for the whole Christian Orthodox Faith. [...] But if you don't come to the assembly for advice, the Great [Cossack] Host will punish you, your wives and children will be cut down, your houses destroyed, and your goods confiscated. ${ }^{61}$

\section{Circulating the Written Word: The Government}

The complex relationship between rebels and loyalists is perhaps best illustrated by the Kadom-Kasimov episode. In November 1670, Kirill Khlopov, an official of Kasimov, sent six monks and two men from the postal service to Kadom, with letters from the tsar urging the people of the district "to keep clear of the blackguards and traitors and make repentance." Unfortunately, the governor of Kasimov, Mihail Dmitriev, deaf to Khlopov's entreaties, decided to execute four peasants from Kadom, presumably suspected of rebellion, while Khlopov's agitators were still in Kadom. Khlopov reports : "Thereupon the Kadom people, hearing this and enraged by the hanging of four peasants of their town [...] lynched four of my envoys. ${ }^{\prime 62}$ Obviously, in hanging the peasants, the governor had violated an unwritten rule, something akin to diplomatic immunity as long as talks were going on. A letter from four rebel atamans to an officer of musketeers confirms this: "As soon as you receive this note, please release our man, Semen Tatarinov, whom you took yesterday. And yet yesterday we were ready to meet you, to talk together for good counsel, and we sent him to talk to you, hoping [to succeed]."63

60 A. I. Kopanev, "Nakhodki bibliografa (Neizvestnye materialy o krest'ianskoi voine pod predvoditel'stvom Stepana Razina)", Trudy biblioteki Akademii Nauk SSSR i fundamental'noi biblioteki obshchestvennykh nauk AN SSSR, vol. VI (Moscow-Leningrad), 1962, p. 210-216, 212 (date unknown). "Loaves of bread" may be part of the traditional welcome, with bread and salt, or more prosaically food for Ivanov's men.

61 Krest'ianskaia voina, II/1, n²07, p. 252; November 1670.

62 Ibidem, II $/ 1, \mathrm{n}^{\circ} 237$, p. 284-285; one of Khlopov's messengers survived and petitioned the tsar in 1672 (ibidem, III, $\mathrm{n}^{\circ}$ 223, p. 251).

63 Ibidem, II $/ 1, \mathrm{n}^{\circ} 221$, p. 270; November 1670. Although the context is somewhat unclear, it seems that the rebels sent Tatarinov in good faith, having perhaps received the oral equivalent of a safe-conduct. 
These attempts at coming to terms did not suit at all the tsar's policy. He ordered all his officers in the field to collect rebel papers, which they did, ${ }^{64}$ but forbade, of course, his subjects to read them. Even to mention the rebel propaganda was considered a crime: for having said, erroneously or on purpose, that a seditious letter had been found in Kurmysh, a peasant was sentenced to have half of his tongue cut out. ${ }^{65}$ Informed that Petr Sheremetev had corresponded with the rebels, Alexis complimented him on his military prowess, but warned him that writing to bandits was not seemly for boyars and officers of the tsar. ${ }^{66}$ The general purpose is clear: Alexis deliberately aimed at a clear-cut line between rebellion and loyalty, the better to suppress the former.

The same line was pursued in foreign affairs. Receiving in November 1670 colonel Nicolas von Staden, bearer of Swedish proposals for an alliance, tsar Alexis instructed him to demand from his principals that "the gazetteers be punished who are printing [on Swedish territory] unseemly pieces about the tsar, ex-patriarch Nikon and Stenka Razin." ${ }^{\circ 7}$

To understand the aspects of the rebellion which have just been described, one needed a really good knowledge of the language and a still better one of Muscovite society. That is why these features have been overlooked by witnesses from Western Europe. They draw a picture in black and white, where exciting tales of massacre and tortures conceal the off-stage talks and, more generally, the deeper mutual understanding that underlies conflict between the two sides in any civil war. The finer details are usually blurred (Fabritius being a welcome exception) under a thick layer of commonplace explanations.

More surprisingly, because revolting non-Russians must have been conspicuous, none of the authors even mentions the Chuvash, Mari, Mordva, Tatars, Bashkirs, who, according to Michael Khodarkovsky, "constituted by far the most numerous and active part of the movement." $" 68$ But that was true only later, in the Middle Volga stage of the rebellion, which the Dutchmen who had escaped

64 E. g., Iourii Dolgorukii writes, in December 1670: "In the current year 179 [1670/71], on different months and days, in different battles, these rebellious letters have been taken from rebellious Cossacks. And these letters we, thy slaves, have sent to you (Krest'ianskaia voina, II $/ 1, \mathrm{n}^{\circ} 323$, p. 407).

65 Ibidem, II/1, n 390, p. 507; January 1671.

66 Ibidem, III, $\mathrm{n}^{\circ}$ 100, p. 109, § 2; June 1671.

67 D. N. Bantysh-Kamenskii, Obzor vneshnih snoshenii Rossii po 1800 god. IV. Prussiia, Frantsiia i Shvetsiia, Moscow, 1902, p. 190-191. Later on, the Russian officials broached the same subject with the Swedish envoy (Krest'ianskaia voina, III, n 236, p. 285-286; December 1672).

68 Khodarkovsky, "The Stepan Razin Uprising", p. 14. 
from Astrakhan did not witness, since they were at that time living precariously as slaves in Persia. When Fabritius came back to Russia, the civil war was over. ${ }^{69}$ As to Martius, living in Moscow he was far from the field, and perhaps his Russian sources did not insist much on this aspect of the rebellion.

\section{WHO TOOK PART IN RAZIN'S REVOLT?}

Can foreign observers be trusted on the nature of the Razin movement, on its social make-up and, more specifically, on its beginnings? Struys has only witnessed the few days in Astrakhan before the storm of the city walls, and escaped before the town was taken. But Fabritius, as we have seen, has faced Razin's men at Chernyi Yar, and lived among them for a few weeks, at first hidden and in Cossack disguise, then in the open, when he "was taken by everyone for a Cossack", to the point of taking his share of the booty. He has met Razin twice, and the rebel chief apparently felt towards him something like benevolence, perhaps because of his skills as an artillery expert. ${ }^{70}$

Painful memories combining with class prejudice, the general picture given of the rebels is utterly unfavourable: "riff-raff", "Rabble", "gemeine Kanalie", "scoundrels", "leichfertiges Gesindel", "ruffians", "curs", etc. But at closer inspection of the texts, one finds that these pejoratives are not distributed at random. The Cossacks are described as "killing everyone and looting everything that came their way", ${ }^{71}$ whereas musketeers and other soldiers who defected to Razin, or revolting townsmen, are called "rascally" or "treacherous streltsy", "irresponsible scoundrels", "bloodthirsty curs", and the like. This might be a calque from Russian documents, e. g. a report, dated December 1670, by Avvakum Ievlev, governor of Efremov: "blackguardly Cossacks" (vorovskie kazaki) and "Tambov traitors" (izmenniki tambovtsy). ${ }^{72}$ In any case, it fits the facts, since the Cossacks were clearly the initiators of the movement; it also draws the line between independent "march warriors", who only broke vague pledges of good conduct, and

69 Fabritius, p. 90-91.

70 "I too had to take my share, but what my feelings were God only knows" (ibidem, p. 87). He first met Razin when the latter came back from his Caspian campaign (p. 79: "Stenka came with us to Astrakhan"), then when appealing to Razin for his countryman Butler (p. 86-87; "artillery expert": footnote 2).

71 Ibidem, p. 70.

72 Krest'ianskaia voina, IV, $\mathrm{n}^{\circ} 24$, p. 25 ; vorovskoi or the corresponding verb vorovat' mean any kind of breach of accepted patterns of behaviour, from forging a testimonial in a law suit to kindling civil war. 
regular forces, or town and country people, who had solemnly sworn on the Cross allegiance and loyalty to the tsar.

\section{Everyone a Cossack?}

A remarkable feature of the 1670 rebellion, as compared to previous (Bolotnikov, 1606) or subsequent (Pugachev, 1773) movements, is its fidelity to Cossack institutions. There is no attempt at setting up a mock court or an imitation of Muscovite official bureaus: krug assemblies and elected atamans are supposed to meet the needs for organization in rebel-controlled areas, since all rebels became, at least in theory, members of the Cossack Host. How deep did this overall identification with the Cossacks go?

When it came to storm Astrakhan, writes Fabritius, "the Cossacks had persuaded the common workers, or jariski (as they are called), to attack the quarter where the Dutch sailors had been posted". As this was the most dangerous place, because "these Dutchmen knew how to handle guns", it appears that Cossacks used the poorest townsmen as cannon-fodder. ${ }^{73}$ This statement is, to some extent, substantiated by the only published letter written by a rebel ataman to another: "And I'd be glad to come back to you, in Kuzmodem'iansk, only the populace (chern') won't let me go, because here, on the Vetluga, they are shouting for help 'The lords are coming!', and wherever they [the lords] meet the populace, they cut them down." ${ }^{74}$ Stenka Razin used the same term, as far as we can judge from the largest message apparently issued directly from him:

This is Stepan Timofeevich adressing all the populace. Who will serve God and the tsar and the Great [Cossack] Host and Stepan Timofeevich, I have sent out Cossacks, and together with them you should exterminate traitors and exterminate bloodsuckers out of the community. And as soon as my Cossacks start to fight in earnest, you go to them for advice, and [you,] all indentured and banished men, join the army and my Cossacks. ${ }^{75}$

Although perhaps without derogatory intention, the Cossack leaders freely use the word chern', usually applied to the lower classes of Muscovite society, from the country and the towns. It should be remembered, moreover, that Cossacks were no

73 Fabritius, p. 84; jariski (more correctly iaryshki) are unskilled labourers employed on ships, in docks, mills, etc.

74 Krest'ianskaia voina, II/1, $\mathrm{n}^{\circ} 169$, p. 202; October 1670 . The author is Il'iushka [Il'ia] Ivanov, mentioned above.

75 Ibidem, II $/ 1, \mathrm{n}^{\circ} 53$, p. 65 ; before September $14^{\text {th }}, 1670$. 
peasants, and even despised husbandry. ${ }^{76}$ At best, they protected peasants in a patronizing way, and admitted them in their midst, but I doubt very much that they ever considered them as their equals. Fabritius, who should know, speaks ironically of these newly hatched Cossacks: "So kamen die neiwe Kosacken, dehnen das Rantson von den armen Leuten versprochen wahr", 77 and so does, when caught in November 1670, Semen Tatarinov: "In the small fort of Lysogorsk, there are [...] six peasants or peasants' sons, who pretend deceitfully to be Don Cossack atamans.",78 $^{, 78}$

It appears that, whatever their appeal to the rural and urban population, the Cossacks clearly remained the undisputed leaders and organizers of the movement, as well as the nucleus and spearhead of the rebel army. The strategy, such as it was, and the aims of the rebellion were decided by Cossacks alone. ${ }^{79}$

\section{What Were the Cossacks Fighting for?}

The foreign narratives give a somewhat contradictory answer to this question. Being born robbers (or so Fabritius and Struys imply), their first objective obviously was to plunder, a view fully confirmed by the evidence. Russian sources even give some idea of the nature and size of the booty. In 1671, a group of Tatar mirzas [nobles] from Temnikov complain that their houses and estates have been looted: Umriak Dosaev's damages are estimated at 500 roubles in cattle and cloth, not counting the currency and the land deeds; Alei Dolatkozin, whose list of stolen goods resembles very much a milliner's catalogue, evaluates his losses at 217 roubles in furs, bonnets, jewels, cloth and linen; his weapons, pewter and copper ustensils, etc. are also listed as stolen; Aidar son of Tokhtar, prince Shihmamet, declares a round price of 600 roubles, plus the land deeds. ${ }^{80}$ The deti boiarskie [petty nobles] from a village in Kozlov district petition the tsar in March 1671 for help: many of their "men" (serfs or slaves?) have been killed, their houses

76 M. Khodarkovsky, "The Stepan Razin Uprising", p. 4: "In the second half of the $17^{\text {th }}$ century when some of the recent arrivals to the Don attempted to farm, the Cossack administration ordered them beaten and plundered, and instructed them to go back where they came from if they wanted to farm".

77 Zapiski, p. 26.

78 Krest'ianskaia voina, II/1, n² 223, p. 272; about Semen Tatarinov, see footnote 65.

79 I have expressed more or less similar views in: A. Berelowitch, "Une jacquerie moderne : la révolte de Pougatchev, 17 septembre 1773-15 septembre 1774”, La Revue russe, n 27 (2005), p. 37-59, 48-51.

80 Krest'ianskaia voina, IV, $\mathrm{n}^{\circ} 41,43,44$, p. 36-39. 
ransacked and burnt, their wives, children and cattle taken away. ${ }^{81} \mathrm{~A}$ minor clerk (pod'iachii) in Temnikov explains that his wife has been tortured by rebels to reveal where the money and crockery were. ${ }^{82}$ In comparison, the Astrakhan booty seems negligible: when it was divided, since "there were several thousand men more than they had reckoned [...] each fellow's share did not exceed ten Reichstaler.",

But even exceptionally bold robbers do not usually try to reform society, to take over entire countries, or even big towns, ${ }^{84}$ and neither do they, as a rule, aspire to the throne. According to foreign witnesses, Razin and his followers did just that, almost from the beginning of the second campaign. "Here [in Panshin, May 1670] he began straightaway quietly gathering the common people around him, giving them money, and promises of great riches if they would be loyal to him and help to exterminate the treacherous boyars." ${ }^{85}$ A speech in the same vein, allegedly delivered by Razin to his army after Chernyi Yar, and probably pieced together by Struys, incriminates the "tyrants" who had so long oppressed them, and proclaims that he will relieve "his children" of their burden. ${ }^{86}$ The most convincing materials are given by the Relation, when depicting the final stage of the rebellion:

Every where he promised Liberty, and a redemption from the Yoak (so he call'd it) of the Bojars or Nobles, which he said were the oppressors of the Country [...] He, Stenko, was come by order of the Great Czar to put to death all the Bojars, Nobles, Senators, and other great ones [...] as Enemies and Traytors of their Countrey [...] [Razin's followers] were commonly put upon the Rack, and being examined, what they designed in this Rebellion, they answered, that they intended for Mosco, and would have the lives of the Nobles, and other great ones. ${ }^{87}$

81 Ibidem, IV, $\mathrm{n}^{\circ}$ 52, p. 46.

82 Ibidem, IV, n² 26, p. 26; December 1670.

83 Fabritius, p. 87. The Reichstaler contained 25.98 g. in pure silver, the rouble represented about $43.7 \mathrm{~g}$.

84 With the exception of Sir Francis Drake, but he was a privateer, tacitly approved by the Queen. Cf. the epigraph by Simone Weil.

85 Fabritius, p. 79-80.

86 The French translator obviously took a hand, too: "Enfin mes amis vous voilà libres, \& ce que vous venez de faire vous affranchit du joug des tyrans. Ce joug est si lourd \& si rude, qu'il y a de quoi s'étonner que vous l'ayez porté si long-temps sans en être accablés. Mais le juste Ciel ne l'a pas permis ; il a été touché de vos larmes, il vous envoie un Libérateur [...] qui vous aimera comme ses enfants \& n'aura pour vous qu'un cœur de père" (Struys, p. 176).

87 Relation, p. 97, 98, 99. 
This last statement is amply borne out by numerous Russian questioning minutes.

Although the majority of foreign witnesses describe Razin as an autocrat ${ }^{88}$ and assume that he coveted the throne, none has more forcefully expressed Razin's ambitions than Martius. After comparing him to Catilina and Wilhelm Grumbach, ${ }^{89}$ he writes: "This was a harbinger of terrible trouble to come, since things had come to such a point, that it seemed there was no way to end the disorders but either the tsar, or Razin should die."90 This fits Michael Khodarkovsky's conclusions perfectly: "Both Razin and the tsar insisted on representing the 'true' tsar and the 'true' church. They were not competing for different conceptions of sovereignty and social values, instead they were vying for the same source of legitimacy." $" 1$

If true, the fact is indeed puzzling, no more so, but just as much as, the illiterate Pugachev undertaking to impersonate the late emperor Peter III. Struys himself, the most fanciful of our witnesses, is at a loss to explain how what might have been a somewhat protracted plundering foray had grown into a full-fledged crusade, or jacquerie, against social order at large. The best he has to offer is that "Radzin being arrived to this Pitch of Greatness was so puffed up as if he had conquered all the Empire." $" 92$ Whatever the origin of this alleged bid for the throne was, it would imply that Razin, with utmost cynicism, first involved the Cossacks, then the "common people" in his selfish plans, under the guise of fighting the boyars. Indeed, some foreign observers (Struys, Martius) depict Razin as a cold-blooded murderer, maddened by ambition, and ascribe to him alone the origin and making of the whole rebellion. This does not fit, somehow, the impression gained from the available shreds of evidence, but on that point, as on many others, our

88 'L'on ne connoissoit Radzin que par le respect qu'on lui portoit, nul ne l'approchant qu'à genoux \& le visage contre terre. Et quand on lui parloit, il étoit défendu de le nommer autrement que Batské, c'est-à-dire Père dans leur langue" (Struys, p. 173).

89 Inostrannye izvestia, p. 45, § 14-15*. W. Grumbach (1503-1567), a noble from Franconia, who tried to fight for prince Johann Friedrich the Younger against Augustus, Elector of Saxony.

90 Inostrannye izvestia, p. 46, $\S 20$ : "Hoc vero demum futuri motus maxime terribilis classicum erat, rebus quippe jam in eum locus deductis, ut tumultus, cujus componendi ratio non apparebat, vel Tzaris, vel Razini exitio terminaretur." The "harbinger" was Razin's claim that ex-patriarch Nikon, actually detained in Kirillo-Belozerskii monastery, and tsar Alexis' son Alexis († 17 January, 1670) were among his followers.

91 M. Khodarkovsky, "The Stepan Razin Uprising”, p. 17.

92 Struys, p. 192; but the French version goes further : "L'Armée de Radzin croissant tous les jours, il en devint si fier qu'il [...] ne douta pas qu'il ne fût bientôt sur le trône de ses voisins. [...] Dans cet esprit d'orgueil secret, il se mit en tête de s'égaler aux Têtes Couronnées." (Struys, p. 179-180). 
documentation is silent or ambiguous, and Razin's personality and ultimate plans remain an enigma.

A better way to approach the problem would be perhaps to start from the other end, from the general state of mind in the Lower and Middle Volga region on the eve of the rebellion. As far as we can see, it was a tangle of resentment, hatred, hope, thirst for justice, perhaps nostalgic yearning for the roving life of yore. ${ }^{93}$ All this Razin, being a natural leader, perceived and crystallized, becoming at the same time the focus of and the driving force behind the movement. But we mustn't expect ever to determine how far he intended to use the rebellion for his own ends.

As for the Cossacks, they were no Robin Hoods, and probably did not think so much of redressing the wrongs of Muscovite society as of taking the place of the nobles - a surmise put forward by Aleksandr Stanislavskii regarding the Cossacks of the 1610-1620's. Some of them were given estates during the first half of $17^{\text {th }}$ century, but what they really wanted was to become government-appointed beneficiaries of a regular "feeding" income (kormlenie or pristavstvo), thereby supplanting the nobles as exploiters of the peasantry. ${ }^{94}$ If Cossack society was as primitive as Nikitin says, ${ }^{95}$ it is no wonder they closely resemble the Bacaudæ, who "seem to have had no social programme other than an exchange of roles between themselves and the landlords." usual scope of operation, they didn't transform it. The faithless "common people" is another matter altogether.

\section{WhO JOINED THE COSSACKS?}

If asked "who joined the Cossacks?", the Western witnesses answer, as one man, "the common people": "In the Space of 5 days after he had got the Astrachan Fleet, his Army was raised from 16000 to 27000 Men, being a mixt of Pesants, Slaves, Tatars and Cossacks, and men of restless minds from all Parts"97; "at this time [1669] Stenka had an opportunity of [...] becoming acquainted with the mood of the common people." 98

93 Cf. Boris Chichlo, "Sibérie: mode de colonisation - mode de production", Sibérie II. Questions sibériennes, Paris, 1999, p. 95-118.

94 A. A. Stanislavskii, Grazhdanskaia voina v Rossii v XVII v., Moscow, 1990.

95 See footnote 23.

96 Moses E. Finley, The Ancient Economy, London, 1973, p. 89.

97 Struys, p. 191.

98 Fabritius, p. 79 
This is not absolutely accurate. Not all peasants joined the movement, ${ }^{99}$ and many who joined did so under duress. Conversely, there was a sizable number of recruits from privileged or semi-privileged classes. In June 1671, the governor of Kadom reports that "city dwellers of Korsun of all conditions have mutinied", ${ }^{100}$ but there are more specific indications in the documents. To give but a few examples: petty noblemen from Kurmysh, Penza, Kozelsk, Voronezh up to a colonel of Circassians in Ostrogozhsk, ${ }^{101}$ a public writer on oath from Lyskovo, a dragoman from Astrakhan, a priest turned ataman who plundered goods to the amount of 2070 roubles and kidnapped a six-month old baby. ${ }^{102}$

Nevertheless, on the whole, Struys, Fabritius, Martius are right: this was a popular revolt, joined by sundry renegades from the upper strata of Muscovite society.

\section{WhY JOIN THE COSSACKs?}

Nearly all Western documents mention the deep-rooted, long-suppressed hatred felt by the lower classes for the boyars (which sometimes means not only the highest rank in Russian Court, but other noblemen as well), officials, officers in the army, landlords - their masters and oppressors - as the main cause of the revolt: the common soldiers "at once decided that this was the chance they had been waiting for so long [...] The murderers [who] had so long thirsted after blood" (Fabritius). "Hence a rumour spread that boyars, against whom there was implacable hatred, were trying to take all the power in their hands [...] So that in the year 1667 Stephan Razin aroused minds already prepared for rebellion."

Neither is it contradicted by the events, reflected in Russian as well as in foreign sources. In the Astrakhan region, the rebels

99 For instance, Ivan Ovchinnik, a serf of Kharlam Ofrosinov, being asked by rebels to give them bread and sheep, called them "good-for-nothing tramps", and was killed accordingly (Krest'ianskaia voina, III, $\mathrm{n}^{\circ} 118$, p. 128; July 1671).

100 Ibidem, III, $\mathrm{n}^{\circ}$ 95, p. 101.

101 Ibidem, II/1, n 126, p. 151, captured in October 1670 (Kurmysh); II/1, n ${ }^{\circ}$ 155, p. 183 184, hanged on October $21^{\text {st }}, 1670$ (Penza); III, n ${ }^{\circ} 30$, p. 38 (Kozelsk); III, n 178 , p. 199 (Voronezh); II/2, n² 29, p. 38-39, n 32, p. 41-42 (Ostrogozhsk).

102 Ibidem, II/1, n 161, p. 190-192; October 1671 (public writer); III, n 298, p. 375-376 (dragoman); IV, $n^{\circ} 38$, p. 34 (ataman-priest).

103 Martius, $\S 13$, p. 43-44: "Inde rumor spargebatur, Bojaros, erga quos implacabile odium erat, omnem potestatem ad se trahere conatos [...] Inde anno MDCLXVII Stephanus Ratzinus præparatos rebellioni animos commovit." 
committed many inhuman acts, and murthered the Gentry, who were fain to betake themselves to Astrachan disguised in Slaves Apparel. The Pesantry who indeed are very tyrannically dealt throughout all the Emperours Dominions, here found an occasion to be revenged of their Liege-Lords, and to show their Man-hood brought the Heads of their Lords and threw them at the feet of a Provost or Executioner thereto ordained, who gave them a reward for their Pains. ${ }^{104}$

In the Middle Volga, "all the Russian Countrey-men living in this Tract, and belonging to Muscovian Lords, rose up against their Governors killing and hanging them." "105 Revolted peasants themselves confessed afterwards, when put to the question, not the murders, but the looting of noblemen's estates. ${ }^{106}$

Of course, official epistles, full of ponderously compounded platitudes, did very little or nothing to pacify the countryside. They could not compete with the brief, fiery messages of the atamans, which said nothing much, only "Be standfast, stand together with us", but had all the glamour of novelty and excitement. Indeed, the attraction of the Cossack way of life, one could almost say "the Cossack style", was a significant factor of the rebellion. Fabritius mentions a Polish nobleman who took him under his protection in Razin's camp: "Wonsofski [...] had been captured a year before by the Cossacks and in the meantime had come to like loose life [das lose Lehben]"; he now commanded a company. ${ }^{107}$ At an earlier date, Russian sources describe in detail an attempt to recruit new Cossacks, thus providing us with a short-range view of Cossack seduction.

On July 20, 1666, four non-commissioned officers and an orderly of colonel Kravkov's regiment gave evidence:

a man, rank and condition unknown, met us at the ferry, and started to invite us to come to the Don Cossacks' settlements. He called himself ataman, and [promised us] 10 roubles, and a horse with saddle, and a sabre apiece. On the morrow, he said, there would be 1700 Cossacks at the Serpukhov ferry. Once on the ferry, he told a girl 'Were you younger and prettier, we'd have use of you in our Cossack krug.

104 Struys, p. 191-192.

105 Relation, p. 98.

106 Krest'ianskaia voina, II/1, $\mathrm{n}^{\circ} 110$, p. 129 , October 1670 , and $\mathrm{n}^{\circ} 218$, p. 267, November 1670.

107 Fabritius, p. 83. 
All this is confirmed by different witnesses, and the man's identity was soon revealed: he was page (zhilets) Emel'ian Vasil'ev Naryshkin, ${ }^{108}$ but he stoutly denied, not very plausibly, all he was charged with, including his none too tactful attempt at flirting and unsuccessful borrowing of tobacco. ${ }^{109} \mathrm{He}$ was probably sent by Vasilii Us. The total catch of the tsar's forces in July-August 1666 includes another noble, a run-away slave from Moscow, five peasants "led astray" by an exserf of Moscow noble (moskovskii dvorianin) prince Ivan Golitsyn, and three domestic slaves (dvorovye liudi) of his fellow courtier, Stepan Fedorov Zhdanov. ${ }^{110}$

\section{THE SPARK THEORY}

Considering the events in retrospect, it seems that the turning point of the whole rebellion was the defection of prince L'vov's army at Chernyi Yar. Had they stood fast against Razin, the Astrakhan revolt would probably not have occurred, or at least would have remained a local affair. Only moments before the defection, they had "unanimously shouted: 'Yes, we will give our lives for His Majesty the Tsar, and will fight to the last drop of our blood." "111 How are we to explain this volteface? It is true that, according to Struys, in Astrakhan, even before the Chernyi Yar defeat, musketeers "who had not in a long time received Pay [...] found now occasion to grow mutinous". ${ }^{112}$ The French translation is even more explicit, with a clear hint at desertion. ${ }^{113}$ Other soldiers, in the course of the rebellion, showed their unwillingness to fight by abandoning their posts. ${ }^{114}$ To join the rebellion was quite a

108 Judging by his subaltern, but nevertheless Court rank, he could belong to the Naryshkin family, who gave tsar Alexis his second wife in February 1671. He isn't to be found in the Naryshkin genealogy (A. B. Lobanov-Rostovskii, Russkaia rodoslovnaia kniga, $2^{\text {nd }}$ ed., II, Saint-Petersburg, 1898, p. 5-18, 463-464), but then he wasn't the sort of man the tsar's in-laws would readily boast about.

109 Krest'ianskaia voina, $\mathrm{I}, \mathrm{n}^{\circ} 22, \mathrm{p} .49-52$.

110 Ibidem, I, n² 28, 29, 30, 32, p. 57-58, 60-61, 64. Ivan Golitsyn, Boiarskaia kniga 1658 goda, N. M. Rogozhin, V. A. Kadik, ed. (Moscow, 2004), p. 147; Stepan Zhdanov, ibidem, p. 189; the 1658 Court register remained in use up to 1676 (ibidem, p. 5).

111 Fabritius, p. 81.

112 Struys, p. 191.

113 "Les soldats [...] disoient hautement qu'ils alloient quitter le service, qu'il n'y avoit plus de quoi les payer, \& que l'argent qu'on leur destinoit étant employé à d'autres usages, il n'étoit pas juste qu'ils continuassent à vouloir exposer leurs vies dont on avoit si peu de soin.” (Struys, p. 179).

114 Struys, p. 191. 
different, and a much more dangerous, prospect. To understand what happened, we must examine the evidence more closely, after attempting to deal with two popular misconceptions of revolt, all the more pervasive because they are only halfconsciously professed.

One of them is of the materialistic persuasion: if enough grievances accumulate within a given social group, it will result, almost mechanically, in an insurrection, because the tension becomes unbearable. A pyrotechnic variation of the same compares popular anger to a powder magazine, which needs only a spark to explode. The other, walrasian, rationalistic approach imagines a potential rebel weighing carefully the pros and cons, and deciding for rebellion if and when the former tip the scale. Both interpretations have something in common: they exclude altogether psychology, and freedom of choice as well.

Revolts, however, do not work that way. The powder keg may be full to the brim, but it still needs, to blow up, a specific operation of what, for want of a better word, we shall call the psyche. Actually, the whole human being is involved; an overwhelming rush of feeling brings every faculty to its highest, feverish level. ${ }^{115}$ Since rebellion implies the infringement of sacrosanct Order (see above), this trance-like moment, sometimes bordering on madness, is essential in order to overcome fear. This is not to deny that the final outcome is the result of a long chain of factors, and that rational arguments are still remembered by the subject. ${ }^{116}$ But they are suspended at the last second: loyalty, fear of punishment, resentment of past injustice, class-hatred, solidarity and twenty others alternate in his mind at lightning speed, until the leap into the unknown, which is the mark of genuine revolt. In a very short timespan, the decision is made: taking chances, assuming risks, and resolving, if need be, to sacrifice one's life ("They swore with life and limb to stand together" ${ }^{, 117}$ - a stereotype of all rebellions and conspiracies). For death is not only, in such a case, a perfectly realistic expectation, it is also the ultimate proof of commitment.

This timeless quality of revolt has been remarkably expressed by Michel Foucault, speaking about the 1979 revolution in Iran: "Uprisings do belong to history, but somehow they elude it. The gesture of a man alone, a group, a minority or a whole people rising up and saying 'I will obey no more' [...] can't be reduced

115 Which accounts for the extraordinary staunchness of Razin's followers, e. g. the "Nun in Man's habit [who] had commanded Seven thousand Men" (Relation, p. 99).

116 Cf. Jacques Lacan, "Le temps logique et l'assertion de certitude anticipée”, id., Écrits (Paris, 1966), p. 197-213, 204 : "Le temps de comprendre et le moment de conclure."

117 Fabritius, p. 81. 
to anything else $[\ldots]$ because the rising man is ultimately beyond explanation."118 If we adopt this view, it follows that no investigation, no matter how ingenuous or thorough, can really come within reach of the crucial moment of the "turn-around" - the actual meaning of rivolta.

Stepping far beyond the borders of a historian's professional caution, I would like to adduce from 1968 France an example which seems relevant to me, although much less risky for the actors than in the case of revolting Muscovite soldiers. Some day around May $15^{\text {th }}$, shop stewards of Renault factory in BoulogneBillancourt had refused access to our group of students and professors. After a while, one of them, partly relenting and talking across the closed gate, told us how the strike had started:

There was no meeting, no instructions from the trade-unions, no leaflets, no talks, nothing. Suddenly, in one of the workshops, a machine-tool stopped, still without a word being spoken. Then another, and another. The workshop went silent, and so did, very soon, the whole plant. The old ones remembered: it had been exactly the same in June 1936.

This "trance" theory was vigorously criticized by several members of the conference. I readily admit that not all rebellions start this way, Swiss peasantry of the $17^{\text {th }}$ century, as studied by Andreas Suter, being a convincing counter-example. I dare say a sentence like "Now, now, the times begin to alter, it will be our turn next to Lord it, you villains" seems to show that plans for rebellion had been laid days, perhaps weeks before. ${ }^{119}$ I'll try nevertheless to uphold my surmise, and for lack of direct proof, to find at least some corroboration: does the "trance" hypothesis help to explain the "particulars of the Rebellion" and some features of its representation? Even if it yields only faint, mostly negative, indications, the matter is perhaps worth a try.

118 Cf. Michel Foucault, “Inutile de se soulever?", in Le Monde, No. 10661, 1979, p. 1-2: "Les soulèvements appartiennent à l'histoire. Mais, par un certain côté, ils lui échappent. Le mouvement par lequel un homme seul, un groupe, une minorité, ou un peuple tout entier dit : 'Je n'obéis plus' et jette à la face d'un pouvoir qu'il estime injuste le risque de sa vie - ce mouvement me paraît irréductible [...] parce que l'homme qui se lève est finalement sans explication : il faut un arrachement qui interrompt le fil de l'histoire et ses longues chaînes de raisons, pour qu'un homme puisse 'réellement' préférer le risque de sa vie à la certitude d'avoir à obéir". My thanks go to Jean-Christian Dumont, who quoted this text in his Servus: Rome et l'esclavage sous la République (Paris, Rome, 1987) and made it available to me.

119 But Struys wrote that in 1676 and may have slightly revised his memories, and anyway there is a quite a gap between conceiving a plan and carrying it out. 


\section{The BLIND SPOT}

Let us look anew at Fabritius' narrative; it is the closest we can get to the state of mind of soldiers in the process of turning rebels. Rather oddly, he writes: "The common soldiers [...] put their heads together and at once decided that this was the chance for which they had been waiting so long, and with all their flags and drums they ran over to the enemy." He seems to imply that the "villains" had already resolved to defect ("the chance for which they had been waiting so long"), and Struys states it ("no doubt they had reached an understanding beforehand"). In that case, what need did they have to hold a council? Besides, if talks had been going on for some time, the officers would probably have heard, or at the very least would have had an inkling of it. What seems more likely is that the final decision was made on the spot, in only a few minutes or even less ("at once").

From Tsaritsyn to Samara via Astrakhan, Razin's rebellion spreads very fast and meets with continuous success. This is consistent with what we know of other rebellions. For some, as yet unclear, reasons, the initial, trance-like outbreak of revolt is electrifying, and therefore tremendously contagious. Its epicenter may be, and often has been, compared to a conflagration, which raises instantly the social temperature to an incredible heat level. It is perceived at once, even from far away, and expands, when the conditions are favourable, with terrifying speed, which makes it well-nigh irresistible. Although remote from the Middle Volga theater, Martius understands perfectly that after the taking of Astrakhan swift movement is Razin's chief asset: "Neither did Razin dally, as a man would, who wished to achieve his aims through rapidity, and endeavoured by every means and plan available to expand his power as broadly as possible."

At Cherny Yar, after the paroxysm, tension slackens: "They began kissing and embracing one another." ${ }^{121}$ But not all effusions of the rebels' souls are dictated by brotherly love: "Murder began at once."122 Why? Of course, human nature being what it is, the worst is hardly surprising. Still, on other occasions, Razin's men, despite their general motto of "exterminating the boyars", have made prisoners members of the ruling class, and the slaughtering of useful gunners could not be really justified by security issues. The explanation by revenge, favoured by Fabritius and Struys, is not completely convincing either. Revenge is individual and cold-blooded. Here we deal with a collective, murderous orgy, such as the one

120 Martius, p. 46, § 19 : "Nec cunctatus est Razinus, ut qui rebus suis festinatione consultum cuperet, et omni ope atque consilio niteretur, ut potentiam suam quam latissime propagaret."

121 Fabritius, p. 81.

122 Ibidem. 
vividly described by Giovanni Verga in an imaginary Sicilian town: as soon as the town-dwellers see the flag on the city-hall which means "freedom", they start massacring the galantuomi (notables) in a truly ghastly way. ${ }^{123}$ This is not such a rare occurrence, and fits e. g. the description of the September 1789 massacres in Paris. Faithful as historians try to be to their pledge of objectivity, it is sometimes difficult for them not to sympathize with the victims and enemies of such a rebellion.

In that respect, the adjective "bloodthirsty", often used by Fabritius when referring to the rebels, is perfectly apposite, in its most literal sense, even to the meaning of "maniacal". Besides, bloodthirstiness is apparently contagious. After obtaining the surrender of Astrakhan rebels, Ivan Miloslavskii was relieved by Iakov Nikitich Odoevskii: the latter

had got so used to torturing people that he could not eat in the morning until he had been to the place of torture and had people beaten with the knout, burned, and put on the rack. But then he could eat and drink enough for three. [...] I had to remain behind and live for nearly a year among these barbarians. ${ }^{124}$

Here, the "trance" theory may be helpful: Foucault has stressed the nobler side of revolt, but there is also a dark side to it. Not only political order, but customary (for Muscovites: Christian) norms of behaviour are thrown overboard as well. Mordlust is given free rein, since it is supposed to be harnessed in a good cause. More than that, it is possible that murder in this context is used as a language. Jan Dhondt, analyzing the political crisis in XII ${ }^{\text {th }}$ century Flanders, concludes that the choice of a prince "is, actually, a very primitive way, the most primitive imaginable, to influence the general policy of the earldom." 125 Murder could represent an even more primitive level of political thinking: actions speak louder than words.

Fabritius must have felt, if not clearly understood, the outburst of passion, akin to lunacy, he witnessed at Chernyi Yar. If so, he did not think it was worth mentioning. For all the remaining observers, domestic and foreign alike, the central moment of revolt remains a blind spot, like an invisible black hole in the course of events. Unable to justify such a tremendous eruption of violence by its causes, they build up a heap of wrong reasons to conceal the gap: ignorance, stupidity,

123 G. Verga (1840-1922), "Libertà", Cavalleria rusticana e altre novelle (Milano, 1994), p. 233-240. I thank Andrea Graziosi, who suggested this parallel to me.

124 Fabritius, p. 92.

125 J. Dhondt, "'Ordres' ou 'puissances'“, Estates or Powers. Essays in the Parliamentary history of Southern Netherlands from the XIIth to the XVIIIth Century, Heule, 1977, p. 25-49. 
intemperance, cowardness, xenophobia, greediness, cruelty or general wickedness is what made the soldiers forfeit their pledge of loyalty. Once again, Martius is nearer the mark: he blames the rebellion on the instability, a characteristic feature, he says, of Russians and Cossacks. ${ }^{126}$

One more question remains: given the hopelessly fierce attachment to routine common to all human beings, are not these temporary fits of madness which we call "revolts" the only way to achieve even moderate changes in the fabric of society the fool's bauble taking the place of "the spirits of the past [...] battle slogans, and costumes in order to present this new scene"? ${ }^{127}$ But that is another story.

126 Martius, p. 40, § g: "Mirum tamen videri potest, quid sit, quod cum gens ista præter ingenitam erga Tzares suos venerationem, servituti assueta sit, tam subito ad seditionem concitandum impelli possit, nisi cognitum esset, ingenia ejus populi esse mutabilis [...]" [One might wonder how it is that a people who, through their inborn veneration for their Tsars, are used to servitude, could be so suddenly impelled to raise sedition, were it not known that they are of a changeable character]. $\S$ h: The Cossacks "genus hominum est instabile, et natura sua quietis impatiens, ac prædandi cupidum" ["are an unsettled race of men, who are by nature impatient of quiet and eager for plunder"].

127 Karl Marx, The Eighteenth Brumaire of Louis Bonaparte (1852). 